Ann. rheum. Dis. (1969), 28, 415

\title{
ENZYMATIC DEGRADATION OF CARTILAGE BY DIALYSED URINE OF RHEUMATOID PATIENTS
}

\author{
BY \\ M BASSIOUNI \\ Faculty of Medicine, Al-Azhar University, Cairo, Egypt
}

In this study urine from patients with severe active rheumatoid arthritis has been investigated for enzymatic activity affecting cartilage.

\section{Material and Methods}

Urine.-This was collected from eight female patients with severe and active rheumatoid arthritis (meeting ARA criteria), one of whom had juvenile rheumatoid arthritis. The erythrocyte sedimentation rate ranged from 30 to $90 \mathrm{~mm}$. in the first hour (Westergren). The WaalerRose test was positive in five and negative in three cases.

Urine was collected for control purposes from eight normal subjects, three males and five females, whose average age (31 years) was the same as that of the rheumatoid patients.

Cartilage.-Fibro-elastic cartilage was obtained from the ears of albino rats and hyaline cartilage from the nasal septa of cattle.

Dialysis of Urine.-Collodion bags of $100 \mathrm{ml}$. capacity were made by coating a clean 100 -ml. glass beaker with 4 per cent. collodion and drying. The collodion bag was filled with urine and dialysed against running tap water for 2 days, long enough to remove all diffusible matter. After dialysis the urine showed mild turbidity.

Procedure.-From the dialysed urine of each patient or control, two tubes were each filled with $10 \mathrm{ml}$. urine. To one tube was added a piece of rat's ear (about $180 \mathrm{mg}$. in weight) and to the other a piece of hyaline cartilage. A similar series was prepared in which the dialysed samples of urine were boiled for 3 minutes before the experiment. A drop of toluene and one of chloroform were added to each tube.

The tubes were corked and immersed in a constant temperature water bath at $40^{\circ} \mathrm{C}$. for 5 days with mild daily shaking and the daily addition of a drop of chloroform.

At the end of the experiment the tissues were studied histologically. Acid polysaccharides were studied in samples of urine before and after incubation of cartilage.
Histological Study.-The material was fixed in 10 per cent. formol saline for 2 days and then embedded in paraffin wax. The rat ears were stained both by haematoxylin and eosin and by orcein. The hyaline cartilage was stained with haematoxylin and eosin only.

Extraction of Acid Polysaccharides from Urine (modified from method previously published: Bassiouni, 1954).

REAGENTS: Sodium hydroxide $2 \mathrm{~N}$
Ammonium Sulphate
Azure A: $100 \mathrm{mg}$. dissolved in $100 \mathrm{ml}$.
distilled water
Formamide
Methyl alcohol
Phosphate buffer pH 7 made up of
$\mathrm{Na}_{2} \mathrm{HPO}_{4} \cdot \mathrm{H}_{2} \mathrm{O} \mathrm{N} / 15 \quad 305 \cdot 5 \mathrm{ml}$. and
$\mathrm{KH}_{2} \mathrm{PO}_{4} \mathrm{~N} / 15 \quad 194 \cdot 5 \mathrm{ml}$.

$7 \mathrm{ml}$. urine were transferred to a $25 \mathrm{ml}$. conical flask, $0.5 \mathrm{ml} .2 \mathrm{~N} \mathrm{NaOH}$ was added and the flask corked and heated at $50^{\circ} \mathrm{C}$. for 30 minutes and then saturated with ammonium sulphate (about 6.5 g.). The flask was shaken vigorously, heated quickly to $75^{\circ} \mathrm{C}$., and filtered. Fluted filter paper (Whatman No. 1) was used, the filtrate being collected in a $12 \mathrm{ml}$. conical centrifuge tube containing $2 \mathrm{ml}$. Azure A solution. The tube was left for an hour and then shaken and centrifuged at 3,000 r.p.m. for 45 minutes. It was then decanted and the precipitate washed first with $5 \mathrm{ml}$. N/100 HCl, and secondly with $2 \mathrm{ml}$. distilled water. The precipitate was dissolved in $0.02 \mathrm{ml}$. formamide, helped by warming to $50^{\circ} \mathrm{C}$. for a few minutes. Finally the solution was applied directly on to paper for electrophoresis, using Whatman No. 1 strips with phosphate buffer at $\mathrm{pH} 7: 500$ volts for 1 hour. The strips were dried, stained with Azure A (100 mg. in $100 \mathrm{ml}$. methyl alcohol), and after drying washed with $\mathrm{N} / 100 \mathrm{HCl}$ twice to remove excess dye.

\section{Results}

Macroscopically the rat ears incubated in urine from rheumatoid arthritis patients showed tearing and fragmentation. It was soft and had lost its 
resiliency. The hyaline cartilage was soft and gave a doughy feeling on pressure. In control experiments, the rat ears were resilient and the hyaline cartilage firm.

Microscopically the rat ears showed tearing and

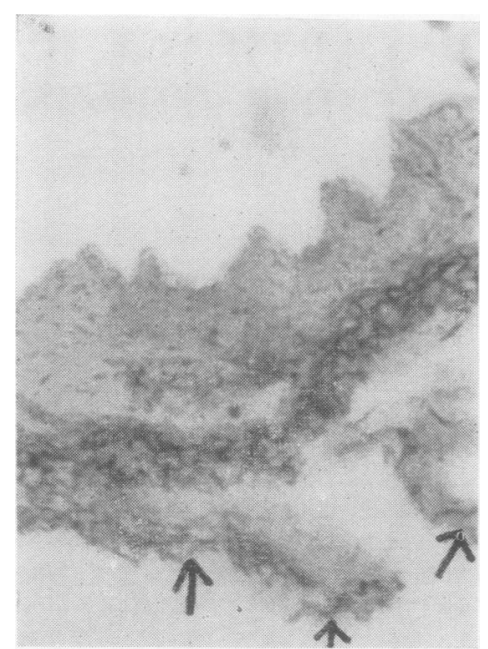

Fig. 1a.-Rat ear incubated in rheumatoid arthritis urine, showing tearing of elastic fibres and degencration of cartilage cells. $\times 120$.

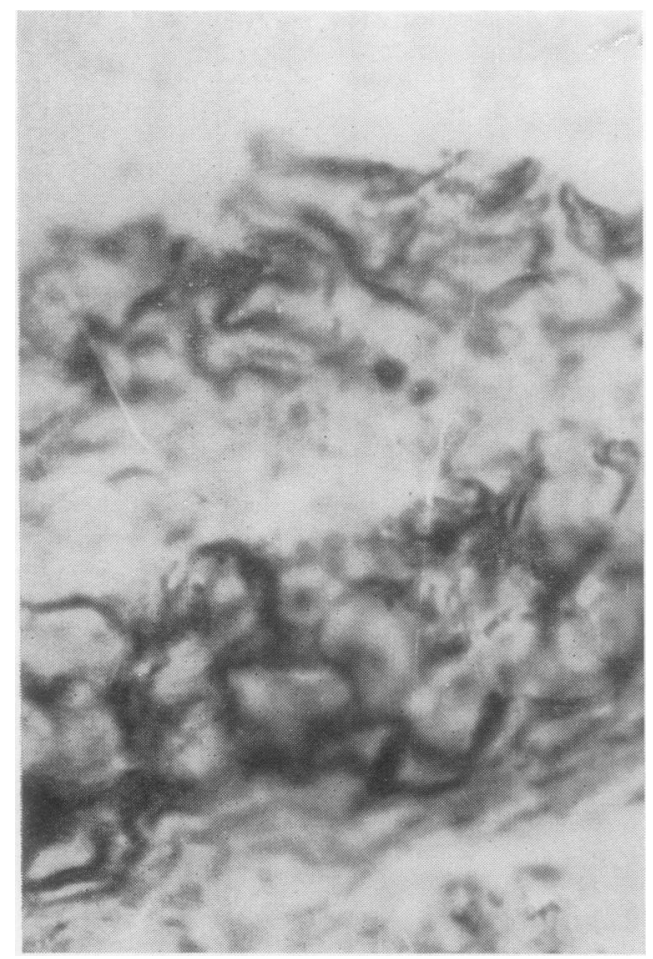

Fig. 2a.-Hyaline cartilage, showing degeneration of cells after incubation in rheumatoid dialysed urine. $\times 1,000$. partial disappearance of the band of elastic fibres lining the cartilage cells (Fig. 1a). Hyaline cartilage was stained only faintly with haematoxylin and eosin and showed degeneration of cells and nuclei (Fig. 2a). No similar observations were

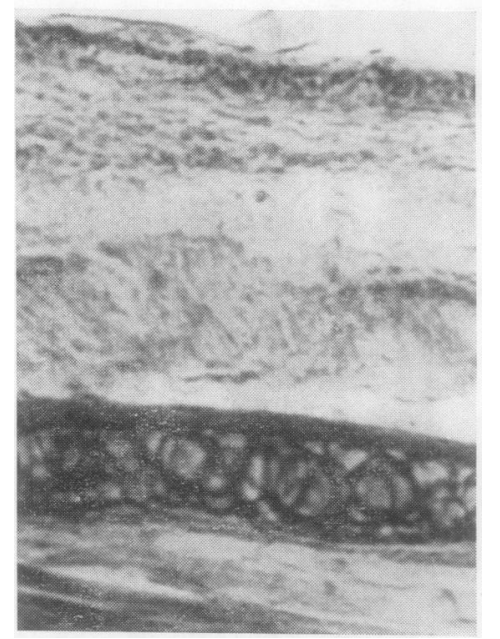

Fig. 1b.- Section of rat ear after incubation in normal dialysed urine, showing no digestion. Hacmatoxylin and eosin. $\times 120$.

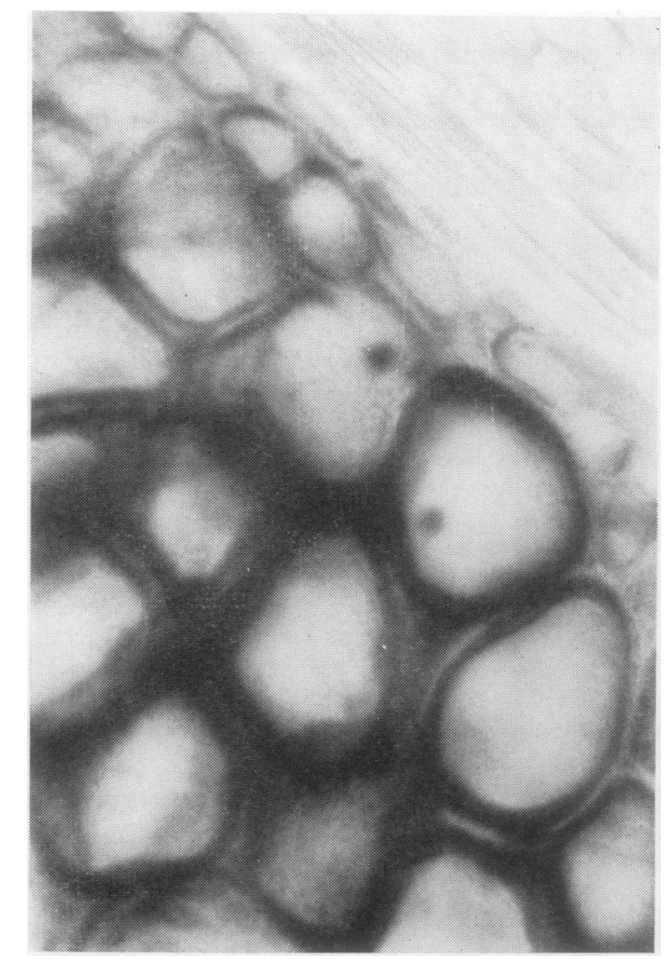

Fig. 2b.-Hyaline cartilage incubated in normal urine, showing normal appearance. $\times 1,000$. 
noted in control experiments using normal urine (Figs $1 b$ and $2 b$ ).

With orcein staining the elastic fibres were very scanty and fragmented as compared with the control specimens.

When incubated in distilled water the two bands of elastic fibres enclosing the cartilage cells remained intact. Some cartilage cells were disrupted by the effect of osmosis but the general architecture was unchanged.

In normal urine the same architecture was preserved, the bands of elastic fibres as well as cartilage cells being intact.

In boiled rheumatoid urine the band of elastic fibres was preserved and the cartilage cells showed the normal pattern, shape, and architecture, with only minor splitting of the cells at a few points, probably the effect of osmosis; this picture was quite similar to that produced by water alone.

\section{Chondroitin Sulphate Isolation and Electrophoresis}

Large amounts of chondroitin sulphate were released from hyaline cartilage incubated in rheumatoid arthritis urine. Chromatographic bands were similar to those given by a direct preparation from hyaline cartilage (Fig. 3).

No similar release was noted in the control experiments.

\section{Discussion}

These preliminary experiments indicate an abnormal activity of proteolytic enzymes in rheumatoid arthritis urine, hydrolysing both elastic fibres and cartilage matrix. The presence of abnormal enzymes in urine has been detected in other diseases, e.g. uropepsin in cases of gastric ulcer and diastase in pancreatic disease. Increased activity of elastase and proteinase in rheumatoid disease was suggested by the high levels of inhibitors of these enzymes in sera from rheumatoid patients (Ardelt, Ksieny, Niedzwiecka-Namyslowska, and Budzynski, 1966).

Degradation of cartilage before pannus formation has been described by Weissmann (1964) and Gardner (1965). According to Weissman, degradative enzymes released from lysosomes may denature the native constituents of cells or connective tissue, and auto-antibodies encountered in the circulation may represent a normal reaction to tissue damage and inflammation. Fell and Dingle (1963) showed that lysosomal enzymes were capable of breaking down the protein-polysaccharide of cartilage matrix.

According to Harper (1963), a cell producing a specific enzyme can increase its enzymatic content from 2 to 1,000 times if a certain organic chemical (a)

(b)

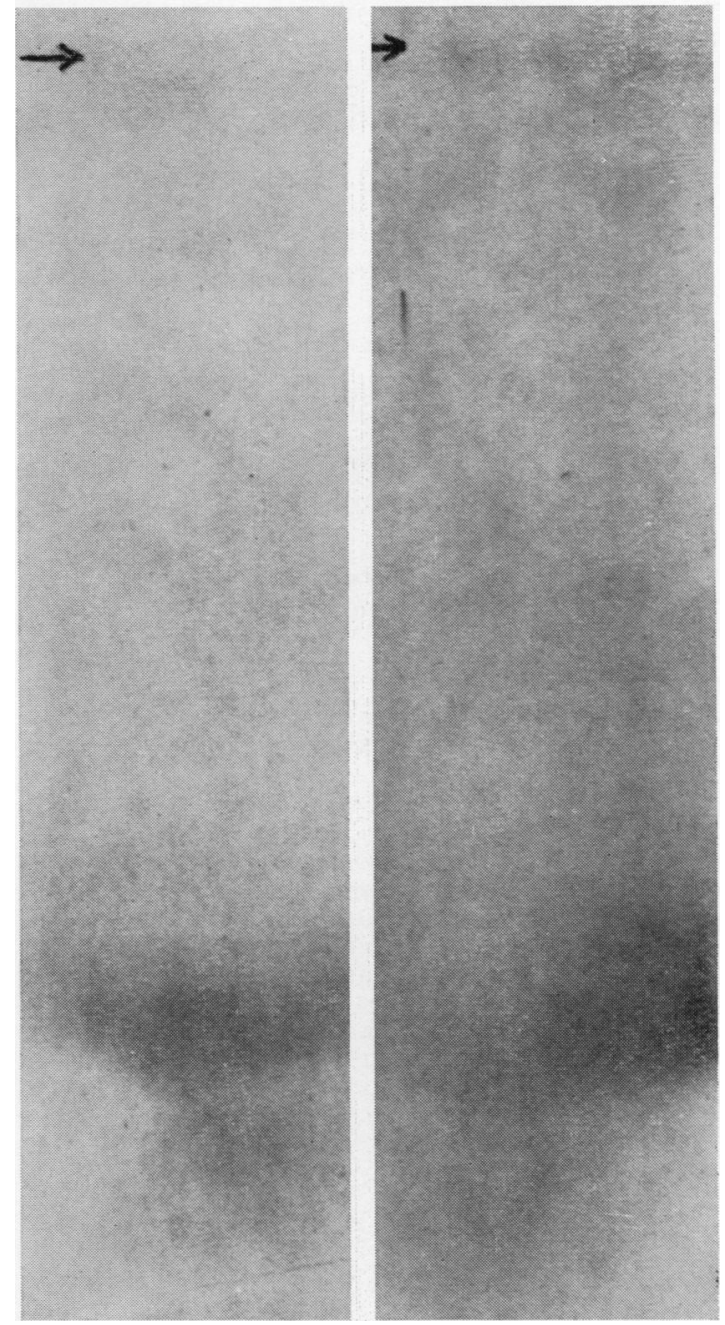

Fig. 3.-Electrophoretogram showing

(a) Bands of chondroitin sulphate extracted from hyaline cartilage. (b) Similar bands of chondroitin sulphate extracted from $7 \mathrm{ml}$. rheumatoid urine after the incubation of hyaline cartilage therein.

No chondroitin sulphate band could be detected in $7 \mathrm{ml}$. dialysed urine in which cartilage had not been incubated.

compound or "inducer" enters the cell and stimulates it. Harper stressed the striking analogies between inducers and antigens. It may be suggested that in rheumatoid arthritis a specific antigen plays the role of inducer to produce high concentrations of proteolytic enzymes which can attack fibres and cartilage matrix.

\section{Summary}

Cartilage from rat ears and from bovine nasal septa incubated in dialysed samples of urine from 
patients with rheumatoid arthritis have been shown to undergo enzymatic degradation. This has been detected histologically by the rupture and disappearance of elastic fibres stained with orcein, faint staining of matrix with haematoxylin and eosin, and destruction of cartilage cells and nuclei with consequent softening and loss of resilience of cartilage. Chondroitin sulphate was released in large quantities by dialysed urine. No such changes were observed using dialysed urine from normal subjects.

\section{REFERENCES}

Ardelt, W., Ksiezny, S., Niedzwiecka-Namysłowska, I., and Budzynski, A. Z. (1966). Ann. rheum. Dis., 25, 450.

Bassiouni, M. (1954). J. clin. Path., 7, 330.

Fell, H. B., and Dingle, J. T.(1963). Biochem. J., 87, 403 (Studies on the mode of action of excess of vitamin A. 6. Lysosomal protease and the degradation of cartilage matrix).

Gardner, D. L. (1965). In "Pathology of the Connective Tissue Diseases", p. 73. Arnold, London.

Harper, H. A. (1963). "Review of Physiological Chemistry", 9th ed., p. 111. Lange, Los Altos, California.

Weissmann, G. (1964). Lancet, 2, 1373 (Lysosomes, autoimmune phenomena, and diseases of connective tissue).

\section{La dégradation enzymatique du cartilage par l'urine dialysée des patients rhumatoides}

\section{RÉSUMÉ}

Le cartilage des oreilles du rat et le septum nasal des bovins incubés dans les échantillons d'urine dialysées provenant des malades atteints d'arthrite rhumatoïde ont montré que la dégradation enzymatique avait lieu. Ceci a été décélée histologiquement par la rupture et la disparition des fibres élastiques colorées par l'orcéine, une faible coloration de la matrix avec l'hématoxyline et l'éosine, et la destruction des cellules et des noyaux du cartilage suivie de ramollissement consécutif et perte de résilience du cartilage. Le sulfate de chondroitine a été libéré en grande quantité par l'urine dialysée. De tels changements n'ont pas été obsérvés en employant l'urine dialysée des sujets normaux.
Degradación enzimática de cartílago por orina dializada de pacientes reumatoides

\section{Sumario}

El cartílago de oreja de rata y de tabique nasal bovino, incubados en muestras dializadas de orina de pacientes con poliartritis reumatoide, han revelado que sufren una degradación enzimática. Esto ha sido detectado histológicamente por la ruptura y desaparición de fibras elásticas teñidas con orceína, leve coloración de matriz con hematoxilina y eosina, y destrucción de células y nucleos cartilaginosos, con consecuente ablandamiento y pérdida de elasticidad del cartílago. La orina dializada puso en libertad grandes cantidades de sulfato de condroitina. Tales cambios no se observaron al usar orina dializada de sujetos normales. 